\title{
Etnografia como antídoto: entrevista com Philippe Erikson
}

Edilene Coffaci de Lima Miguel Carid Naveira Laura Pérez Gil

(UFPR)

Lorena Córdoba (CONICET-UBA)

Diego Villar (CONICET)
Desde meados da década de 1980, Philippe Erikson deu um impulso decisivo ao estudo dos povos de língua pano, notadamente a partir de seus trabalhos de pesquisa entre os Matis, no Vale do Javari, e os Chacobo, na Bolívia, localizados próximos à fronteira brasileira. Professor na Université Paris-Ouest Nanterre (outrora Paris X) e pesquisador do EREA (Equipe de Recherche en Ethnologie Amérindienne), Philippe Erikson tem não apenas recepcionado diversos pesquisadores brasileiros em Paris, mas, sobretudo, incrementado a interlocução entre etnólogos dos dois lados do Atlântico, marca de sua delicadeza e generosidade.

Nesta entrevista, realizada há três anos, em Buenos Aires, durante a realização da VIII Reunião de Antropologia do Mercosul, Philippe conversou com cinco panólogos sobre sua trajetória acadêmica, sua aproximação da Etnologia, sobre sua predileção pela Etnografia, em detrimento das ambições comparativas ou da procura por modelos teóricos que já o acompanharam. A entrevista foi revisada pelo próprio Philippe em julho de 2012, em Curitiba, com duas das entrevistadoras e depois ajustada eletronicamente até alcançar sua versão final, que vai aqui finalmente publicada.

\section{Campos: Como você começou na Antropologia?}

Philippe Erikson: A primeira vez que fiz um investimento na Antropologia, que gastei tudo que tinha, foi em 1969. Estava morando em Nova York e voltávamos para a França. Tinha 10 dólares e não sabia se poderia trocar essa quantidade. Assim, comprei um livro sobre os índios de América que custava nove dólares. Acho que esse foi o início da minha vocação. Lembro que pouco antes, quando tinha sete ou oito anos, li um livro sobre os Astecas e um amigo tinha lido um livro sobre os Maias. Daí eu ia ficar "a serviço dos astecas" (risos). Depois eu li também o livro sobre os Maias, literatura para crianças, e fiquei preocupado porque pensava: "agora sei o 
mesmo que ele sobre os Maias, mas ele deveria ser o especialista. Como é que a gente vai fazer?". Penso que sempre quis conhecer os povos indígenas. Teve um tempo na minha adolescência que pensava que ia estudar Direito, que ia ser advogado, mas isso durou pouco tempo. Pensava que, sobretudo, era necessário conhecer as línguas. Chegar a aprender uma língua tão diferente como a de um povo indígena parecia tarefa de toda uma vida. Chegar a entender o que era uma cultura... Mais tarde, quando comecei a estudar, não sabia como, se queria fazer trabalho de campo na África, na Oceania ou no México; não tinha uma ideia definida. Então comecei a assistir as aulas de Patrick Menget em Nanterre e ele fez com que me interessasse pela Amazônia. Eu admirava muito sua forma de ensinar. Aí começou tudo. Há vinte e cinco anos que me dedico a isto.

Campos: E aquele livro de nove dólares sobre os índios, você lembra qual é?

PE: Ainda estou com ele. O mais engraçado é que acho que nunca cheguei a lê-lo. Tem muitas ilustrações, mas o texto era um tanto denso para uma criança de nove anos e depois passou o momento de lê-lo. Mas está em casa e, quem sabe, um dia o lerei. Trata-se de um livro de Olivier La Farge (The American Indian, special edition for young readers. New York: Golden Press, 1966 [1960]). No ano anterior, no Natal, eu tinha recebido dois exemplares, da parte de cada uma de minhas duas tias americanas, de um outro livro para crianças que era também sobre os índios. Acredito que se chamava algo como How and why tell me book of North American Indians. Este era mais simples e lembro-me de ter lido-o e relido-o inteiro. Ele foi objeto de minha primeira ficha de leitura. Lembro-me de me ter colocado muitas questões, do alto de meus oito anos, sobre o número de nomes de chefes indígenas que era preciso citar em meu resumo do livro. Eu queria colocar todos, mas tive que me dar conta que não podia copiar todo o livro numa ficha de leitura. Talvez aí tenha nascido meu interesse pela onomástica!

Campos: Você iniciou sua carreira diretamente na Antropologia?

PE: Não. Na França os melhores alunos têm a possibilidade de fazer o que é chamado de curso preparatório (classes préparatoires) e foi isso o que fiz, nos liceus Henry IV e Lakanal, não Antropologia. É uma forma de evitar os primeiros anos de universidade e de ter uma forma de ensino mais pessoal, melhor. É mais parecido ao ensino médio porque se estuda um pouco de tudo: literatura, história, geografia, filosofia. O aluno não faz escolhas; não há grandes aulas em anfiteatros. É muito seletivo e difícil. Sofri bastante porque eu queria estudar Antropologia. No terceiro ano, quando finalmente comecei, senti como se um sonho estivesse sendo realizado. Comecei em Harvard, na escola de verão, e foi então que segui um curso de introdução à antropologia. Mas, de volta à França, não escolhi bem a universidade. Como não tinha estudado Sociologia, não fui aceito na Sorbonne (Paris V), onde naquele tempo apenas podiam cursar Antropologia os alunos que tivessem estudado Sociologia. $O$ que era absurdo porque os melhores alunos não estudam Sociologia no curso preparatório! Existia também Nanterre (Paris X, atual Paris Ouest-Nanterre), mas eu achava que ficava muito longe da cidade. Na realidade, são apenas 10 minutos! Então, escolhi Paris VII, em função da sua localização, em Jussieu, no coração de Paris. Entrei lá num momento 
em que estava tendo uma guerra entre Robert Jaulin e André Marcel D'Ans. Manipularam muito os estudantes para expulsar D'Ans, assim que fizemos greves e manifestações ao invés de fazer cursos. Uma vez assisti a uma aula de Patrick Deshayes, que estava voltando de campo e trazia dados provando que D’Ans era sei lá o que... De forma que tudo começou marcado pela política. Por isso desisti; larguei a carreira de Antropologia. Estava também estudando Linguística em outra universidade. Contatei com Roberte Hamayon, que era uma antropóloga muito conhecida na França. Eu tinha estudado com sua filha na escola e sabia que poderia me ajudar. Expliquei-Ihe a situação, que não podia estudar em Paris VII, que não havia biblioteca, que os professores eram ruins e ela me disse: "você deve ler as Estruturas Elementares de Parentesco e ir a Nanterre". Então li Lévi-Strauss (o que era fortemente desaconselhado em Jussieu) e entrei em Nanterre.

\section{Campos: E lá você estudou com Patrick Menget?}

PE: Sim, naquela época sim. Comecei a trabalhar com Patrick e ele deixou que eu escolhesse o tema de pesquisa. Não me deu nenhuma indicação e sofri para decidir o que ia fazer no mestrado. Comecei a ler, e li muito. Os animais apareciam em todos os livros e pensei: "posso fazer um trabalho sobre animais". Patrick me disse: "tudo bem, isso fará com que você leia bastante". Fiquei lendo durante um ano e então comecei a conhecer um pouco a Amazônia. Lembro quando perguntei a Patrick se poderia fazer o mestrado com ele. Enfim, o problema era que não falava nem espanhol nem português: "o que vou fazer?". Ele me disse: "isso você aprende em três semanas, não se preocupe". Mas não, na realidade foi um pouco difícil. O primeiro texto que li em português foi o de Eduardo Viveiros de Castro, aquele famoso escrito com Seeger e Da Matta'; são umas vinte páginas, é curto, mas demorei umas quarenta horas para ler. Pensei que naquele ritmo nunca ia conseguir nada. Mas depois li outra coisa em português, e então o vocabulário era o mesmo, comecei a entender a gramática, e o ritmo melhorou. Em um ano aprendi a ler mais ou menos em português e em espanhol. Não me lembro, acho que li mais em português do que em espanhol. Isso foi em 1983. No ano seguinte, no sistema francês, era necessário escolher onde iria fazer a pesquisa para a tese, e foi um pesadelo porque devia escolher um lugar interessante, já que implicava em um investimento de anos. Lembro-me daquele ano como um ano de dúvida. O interessante era que tinha várias opções. Aurore Monod Becquelin - que tinha sido minha primeira professora amazonista quando eu fiz meu mestrado em Linguística, em 1981-82, e com quem eu sempre, até hoje, mantive uma amizade muito forte queria que eu fosse trabalhar no Xingu, com os Trumai. Mas Patrick achava que seria melhor para minha carreira, e para a Etnologia amazonista em geral, que eu me concentrasse em um outro grupo, menos conhecido. Dos povos com pouco contato estavam os Suruí ou os Cinta-Larga, tinham ainda os povos do vale do Javari, e Ihes dediquei bastante tempo. Numa ocasião, Patrick fez uma descrição do panorama do americanismo em Nanterre e se referiu a mim como o jovem pesquisador que ia trabalhar no vale do Javari. Eu tinha ainda dúvidas, mas ele já sabia (risos). Assim, fiz um projeto solicitando uma autorização para ir aos Matis, Marubo, Matsés ou Mayoruna, como eram chamados naquele tempo. Não sabia exatamente aonde ir no vale do Javari. Pensava que poderia ser mais interessante estudar novamente os Marubo em vez de começar do zero. Mas quando cheguei ao Brasil, fiz 
entrevistas com Alcida Ramos, encontrei-me com Melatti, evidentemente, que foi o meu patrocinador, e não sei mais com quem, Janet Chernela em Manaus, várias pessoas, e todos me disseram: "ah, você é o jovem que vai para os Matis". No Brasil não havia dúvida alguma. Porém, quando cheguei a Atalaia do Norte para ir ao campo, o pessoal da FUNAI queria me enviar para outro lugar, porque seria mais cômodo. Mas eu disse que não; se todo mundo estava dizendo que tinha que ser os Matis, eu devia ir, não é? Viajei com a minha esposa, Hélène, vocês já sabem. Chegamos sem saber quase nada de América Latina, da parte amazônica. A primeira vez que vimos matar um macaco para comê-lo e vimos como o cortavam (risos), foi incrível. Mas hoje Hélène pode cortar um macaco de olhos fechados. E assim foi indo.

Campos: E vocês chegaram lá com a ideia de ficar quanto tempo? Ou não tinham uma previsão?

PE: Não, a ideia era ficar um ano, fazer um ano de trabalho de campo, mas não sabíamos nada das condições de campo. Acho que chegamos a campo com um quilo de arroz e um litro de óleo, porque na França um litro de óleo durava muito, mas felizmente tinha víveres no posto da FUNAI e, em seguida, os Matis se mostraram bastante generosos e nos nutriram em troca de presentes que trazíamos da cidade.

Campos: Você tinha alguma ideia inicial sobre o tema de sua pesquisa? Eram os animais de estimação?

PE: Escolhi um povo pano porque na região pano tinha sacrifícios e matanças de animais que eram raras em outras regiões. Ainda não era sabido naquele tempo, mas os Cinta-Larga e outros também o faziam. Mas sim, eu tinha interesse na relação homem-animal. De todo modo percebi em campo que tinha outros assuntos interessantes, especialmente os ornamentos corporais que eram muito impressionantes entre os Matis. Por exemplo, a primeira vez que chegamos, após dez dias de subida do rio em um barco com motor de rabeta, o conhecido peque-peque, os guias nos deixaram numa trilha, nos indicaram o caminho e foram embora. Lá estávamos sem nada, caminhando, e atrás de um tronco apareceram dois rostos matis, muito impressionantes, e nos levaram até a aldeia. Chegaram as mulheres, em torno de vinte mulheres, totalmente nuas e com os ornamentos; nos rodearam e ficaram falando todas ao mesmo tempo, e, uff!!, foi um golpe e minha cabeça começou a doer com muita intensidade. Depois encontramos o encarregado do posto de saúde que estava sozinho e muito doente. Tinha hepatite e malária ao mesmo tempo, e estava para voltar à cidade (Atalaia do Norte) e, felizmente, chegou aquele barco. E lá nos deixou as chaves, o rádio, remédios: ficamos encarregados do posto de saúde. E os Matis entenderam que nós éramos os que chegavam com a FUNAl, os que iriam se encarregar de tudo, embora não soubéssemos como fazê-lo. Não me lembro de tudo porque isso se passou há vinte e cinco anos atrás. Após uns quinze dias chegou uma equipe de filmagem japonesa e já podíamos servir de guias e até traduzir algumas palavras. Sempre disse que comecei a traduzir o Matis antes de falá-lo.

Não sabíamos exatamente quanto tempo iríamos ficar, mas o que aconteceu foi que as condições logísticas eram terríveis, assim que ficamos todo o tempo que pudemos. E ainda tínhamos comprado um motor e gasolina, 
mas o motor não funcionava; quando chegamos o motor estava quebrado, embora o tivéssemos comprado novo. E a gasolina, é claro, desapareceu. De qualquer forma, nós não tínhamos nem mesmo uma piroga... ${ }^{2}$ Assim, não havia como voltar, e ficamos lá. Após quatro meses tivemos a oportunidade de voltar para a cidade com um comerciante (regatão) para comprar algumas coisas, especialmente comida, que era o que mais nos faltava. A ideia era ficar uma semana para fazer algumas compras e voltar, mas quando chegamos à cidade, o dinheiro que pensávamos que estaria no banco não estava, e tudo era muito complicado. Pensamos em tentar consertar o motor, mas também não foi tão fácil assim. De forma que precisamos voltar com o comerciante após um mês ou seis semanas, não me lembro exatamente. Felizmente, ficamos na casa de Silvio Cavuscens, então voluntário da OPAN, que morava em Benjamin Constant, e que muito nos ajudou. Não tínhamos dinheiro. Chegamos até o ponto que em uma ocasião quisemos fazer uma troca de miçangas com uns Tikunas para comprar alguns abacaxis. Tínhamos umas amostras de perfume trazidos da França e as vendemos a um traficante para conseguir algum dinheiro. Quando, finalmente, conseguimos regressar com bastantes víveres, decidimos ficar até não aguentar mais. E nesta segunda vez ficamos oito meses, o que é demais, especialmente nas condições daquela época. Em relação ao correio, por exemplo, recebíamos nossas cartas com o regatão que vinha quando podia - a cada quatro, cinco ou seis semanas - e aquela era a única oportunidade para enviar cartas. O contato com as famílias era muito complicado. Com os Matis foi desse jeito, ficamos até a ficar sem sapatos, sem lápis, sem nada. Com alguns meses de menor rendimento, vamos dizer, durante os quais se está lá, morando lá, sem trabalhar muito, porque o tempo parece infinito. Quando voltei anos depois por algumas semanas sabia que teria de aproveitar, escrever o tempo todo. Mas quando se fica durante vários meses, é diferente. De qualquer forma, acho que a relação que tenho agora com os Matis seria muito diferente se não tivesse sido tão difícil no início. Por que quando os jovens líderes

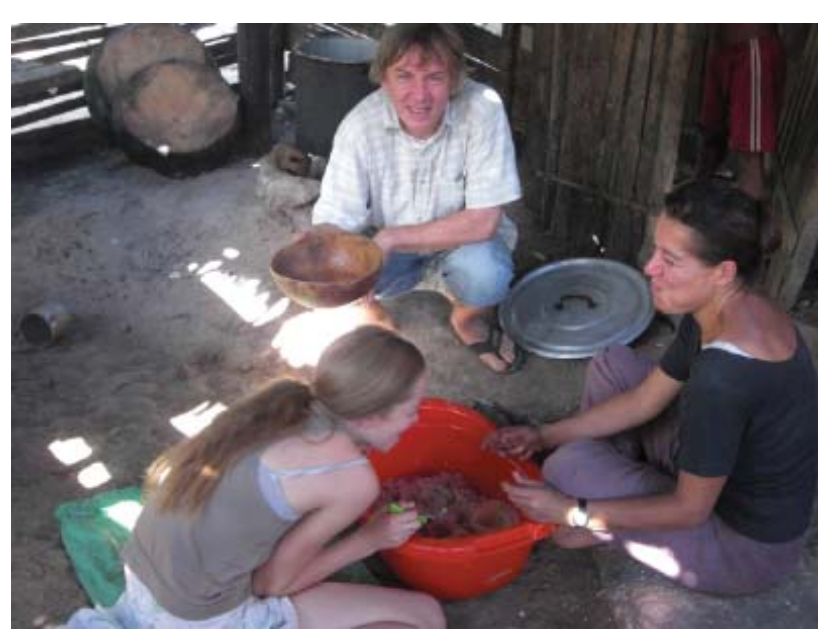

Philippe, sua esposa Hélène e sua filha Anna na comunidade Chacobo, em 2010. Foto de Diego Villar. falam "vocês se aproveitam", respondo "não é assim, não contaram a vocês como passamos todos fome e como sofremos?", e eles dizem: "sim, sim, contaram para mim". $\mathrm{O}$ fato de viajar em casal também foi importante, porque é, por assim dizer, mais natural. Estou pensando mais, quiçá, no trabalho de campo que fizemos depois, a partir de 1991, entre os Chacobo. Fomos com as crianças, com duas crianças pequenas, de forma que éramos uma família normal. Os Matis não entendiam por que minha esposa, Hélène, não tinha filhos. Obviamente porque já estava com vinte e quatro anos.

Campos: Você lembra-se de algum fato do campo em particular entre os Matis? 
PE: Tem um que é bom e ruim ao mesmo tempo. O único conselho terrível que o Patrick me deu foi levar miçangas. O fato é que os Matis faziam as deles próprios e não queríamos introduzir essa porcaria de plástico. Todos os indígenas em Brasil as usavam, mas não os Matis. De forma que chegamos com vários quilos de miçangas e optamos por escondê-los; mas não é possível esconder nada numa aldeia tão pequena. Foi um escândalo, porque eu queria entregar as miçangas aos Marubo, que passavam pelo rio de tempos em tempos, e os Matis ficaram muito ciumentos. $O$ único homem que sabia falar um pouco o português conversou com a minha esposa e ameaçou matála se não fosse embora no próximo barco. Todo mundo nos insultava, foi um desastre. Fomos embora e acabamos na maloca de um senhor chamado Tumi Preto que vivia a uns vinte minutos do assentamento principal, e que era o único "outro" lugar aonde podíamos ir. Esse foi o lado positivo dessa história, porque lá podemos viver a vida comunitária na maloca mesmo. Fomos para lá sem levar nada; deixamos tudo, exceto o terçado e um caderno de campo. Assim, sem quase nada, ficamos três semanas na aldeia de Tumi para escapar dos insultos dos outros. Foi uma época realmente muito agradável de convivência e dessa forma saímos da casa da FUNAl, finalmente. Os Matis viram que a gente podia viver com eles e me autorizaram a construir minha própria casa ao lado de sua maloca. Foi uma aventura que me custou várias semanas! Foi uma etapa muito importante do trabalho de campo. Outra etapa foi quando voltamos e todo mundo tinha saído em expedições de caça e para comer pupunha: não tinha ninguém na aldeia. Veio um homem, Kwini, que depois foi um dos meus principais interlocutores e nos convidou a acompanhá-lo. Ele nunca tinha conversado comigo antes, apesar de estarmos lá fazia cinco meses. O fato é que nos convidou a ir junto com a sua família, de forma que o acompanhamos na expedição dele durante quinze dias, no meio da selva, e isso foi uma experiência inesquecível.

Campos: O que aconteceu com as miçangas?

PE: Expliquei a um chefe matis que não queria entregar as miçangas porque então eles iriam deixar de fazer as próprias, e ele respondeu: "você está nos acusando de sermos frouxos. Você é sovina". Para cada argumento, ele tinha uma resposta melhor, de forma que não tinha solução. Mas a vingança chegou uns vinte anos depois, porque agora todos os jovens têm colares de plástico e eu comento com os mais velhos: "não é verdade que eu tinha razão e que as moças agora não sabem fazer colares, e quando os fazem são muito grossos?". A qualidade dos artesanatos matis mudou um pouco. Continuam sendo muito bonitos, mas não é como antes, por motivos óbvios.

Campos: Você se lembra de alguma coisa que chamou a sua atenção quando começou a viver com os Matis?

PE: O que me parece mais destacado do início do trabalho de campo é o tédio: horas e horas, especialmente no início, quando, saindo da casa da Funai, íamos visitar a maloca, nada acontecia. As crianças se punham a gritar "nawa, nawa" e os cachorros se mostravam particularmente agressivos... Por isso a oportunidade de ir em expedições de caça, caminhar com as pessoas, isso mudou totalmente as relações.. Uma outra coisa que nos chamou muito a atenção (frappés) no começo foi a dificuldade de reconhecer as pessoas por causa de seus numerosos ornamentos corporais. De uma certa forma, não víamos mais que isso. E essa é, sem dúvida, uma das razões pela qual, em minha tese, falei tanto deles! 
Campos: Você faz várias referências à "fase inicial": o que mudou para que você a distingua de momentos posteriores?

PE: Bom, depois do último mês, vamos dizer, depois de onze meses de trabalho de campo tinha a impressão de que começávamos a poder nos comunicar muito melhor em matis. Saímos do campo em 1985. Voltei por pouco tempo em 1988 e percebi, ao trabalhar o material coletado, que tinha feito algum progresso. Comecei uma fase de visitas mais curtas, que poderia ser algo assim como uma "segunda fase". Quando sai do campo em 1985, cheguei à França e todo mundo me perguntava: "e aí, como foi?". Para mim tinha sido um enorme fracasso. Eu pensava que não tinha aprendido nada, que não sabia nada, que não saberia sobre o que escrever a tese, ou se teria de escrevê-la sobre os piums. Aos poucos, trabalhando, percebi que tinha material e que tinha algumas ideias. Mas fiz uma tese muito comparativa porque não tinha muita confiança nos meus próprios materiais: precisava comparar o que tinha com tudo o que tinha sido escrito sobre os outros Pano.

Campos: O que você tinha lido a primeira vez que você foi a campo?

PE: Bom, Patrick Menget e Jean-Pierre Chaumeil (que era então um pós-doutor) me emprestaram os livros. Eu tinha lido as obras completas de Pierre et Françoise Grenand sobre os Wayãpi, e fui passar um longo fim de semana com eles para debatê-las ; foi a primeira vez que dormi em uma rede ; o livro de Anthony Seeger sobre os Suyá me causou uma forte impressão, do mesmo modo que a tese de Descola (também um jovem pós-doutor), que não estava ainda publicada, mas que pude ler na biblioteca. Os trabalhos de Joanna Overing foram igualmente muito importantes na minha formação inicial. Li Queixalós, e certamente por causa de Patrick e Aurore, tudo sobre o Xingu: Agostinho, Basso, Gregor, e até os papers inéditos de Emily Ireland que Patrick tinha trazido dos EUA. Naquela época, antes da internet, havia muito do que a gente chamava de "literatura cinza " (littérature grise), composta de textos não publicados mas que circulavam secretamente, sob a forma de fotocópias, praticamente como incunábulos. Foi assim também que li os primeiros textos de Bruno Illius que Patrick tinha conseguido no Congresso dos Americanistas em Manchester, em 1982. Sobre o Javari e os Pano, li aquilo que estava disponível em Paris, mais o que enviou Melatti, que, como sempre, foi muito gentil. Além disso, tinha lido a tese de Romanoff, a de Woodside, a de Deshayes \& Keifenheim... Também o volume 5 (Javari) de Povos Indígenas no Brasil, do CEDI (atual ISA), que, àquela altura, sabia quase de cor.

\section{Campos: Kensinger?}

PE: Obviamente. Mas tinha poucos trabalhos publicados. Acho que depois da primeira etapa fui visitar Robert Carneiro em Nova York e ele também me entregou bastante material, mesmo cópias de materiais que ele tinha fotografado antes da existência das fotocopiadoras. Carneiro também foi muito generoso, mas tinha pouco material disponível naquela época. Warren de Boer, Pete Roe e alguns outros me enviaram também seus trabalhos pelos correios. 
Campos: Em seu livro você menciona que a tese discutia a hipótese proposta por Seeger, Da Matta e Viveiros de Castro de que o funcionamento da vida social nas Terras Baixas de América do Sul estivesse diretamente ligado aos processos de construção da pessoa através da manipulação corporal.

PE: Agora é muito óbvio que escrevi uma tese sobre o corpo matis, sobre a ornamentação como uma modalidade de corporeidade fabricada, mas sem o saber. Fiz uma tese que era mais como uma monografia comparativa, com capítulos sobre parentesco, etnônimos e coisas do gênero. Mas, no final das contas, toda a literatura teórica sobre o corpo não foi mobilizada a não ser de forma pouco explícita. Estive muito mais concentrado sobre a erudição regional. Sempre estava à procura de literatura sobre os Pano, e sobre tudo isso: foi uma fase da minha carreira marcada pela obsessão pela panologia. A tal ponto que, no Brasil, algumas pessoas brincavam me chamando de “o rei dos panos". Agora já não é tanto assim.

Campos: Em seus primeiros trabalhos pode-se perceber uma certa obsessão comparativa e um nível de abstração muito mais alto. E depois um caminho progressivo para um estilo mais minimalista, com mais atenção ao detalhe etnográfico. Existe um percurso bastante evidente desde os estudos sobre antropofagia e as tatuagens pano, com um estilo argumentativo, para os estudos sobre a ornamentação matis, a onomástica e as saudações chacobo, com maior preciosismo em termos de detalhe etnográfico.

PE: Tem razão e é um paradoxo, porque tem muitos autores que fazem o percurso contrário: começam por trabalhos mais etnográficos e passam depois para trabalhos de cunho mais teórico. Atualmente não tenho muito interesse em modelos abstratos, em preencher modelos pré-fabricados. Pensemos, porém, que o trabalho, por exemplo, sobre os ornamentos matis foi publicado muito tarde, em $2003^{3}$, mas é uma das primeiras coisas que escrevi, para um Colóquio franco-britânico "Physiologie et cosmologie en Amérique Indigène", organizado por Patrick Menget e Stephen Hugh-Jones em Azay-le-Ferron, em 1987 (foi naquela ocasião que encontrei Cecília McCallum, Peter Gow e Graham Townsley pela primeira vez). Assim que, enfim, tinha interesse nos detalhes etnográficos desde o início. $O$ texto mais abstrato ao qual se referem foi o que publiquei em $1986^{4}$, no qual propunha, sobre uma base etnográfica bastante frágil, a teoria do contra-exo-canibalismo, e onde lancei a expressão "alteridade constituinte" que teve, em seguida, um certo sucesso. Mas pouco depois, ou na mesma época, publiquei também coisas marcadamente empíricas, notadamente na revista Antropozoologica ${ }^{5}$.

Campos: Por exemplo, você foi deixando de um lado questões como a de "os panos típicos"...

PE: Sim, obviamente. Uma das coisas que eu queria fazer era estabelecer uma ponte entre a literatura peruana e a brasileira, porque existia um corte muito marcado entre elas. Foi por isso que queria desenvolver também esse assunto da "panologia", para permitir unir ambos os lados da fronteira. Quando voltei de trabalho de campo, fomos morar num pequeno quarto em Paris. Eu não sabia o que fazer e Patrick Menget me pediu que escrevesse um artigo sobre a guerra porque estava preparando um número especial para o Journal de la Société des Américanistes. 
Porém, os Matis são os indígenas menos guerreiros, vamos dizer, de toda a Amazônia, pelo menos entre aqueles que conhecia naquela época. Anos depois, me contaram de vários confrontos, e ficou claro que não eram tão pacíficos como quiseram se apresentar. Como é que ia escrever sobre a guerra se estava voltando de um trabalho de campo durante o qual não testemunhei sequer uma briga entre eles? De qualquer forma, existia uma certa violência na tatuagem, de forma que fiz um trabalho comparativo; não é teórico, mas sim comparativo. Eis a gênese de meu texto sobre antropofagia e tatuagem...

A ambição teórica estava no trabalho que tinha escrito antes de ir a campo sobre os animais ${ }^{6}$; nele havia uma ambição mais global. Lendo os trabalhos sobre a Amazônia parece que determinados elementos apenas existem onde você trabalhou, mas depois você descobre que os Yanomami também o fazem, que os Wichí também, e ainda os Xavante. Então, tem alguma coisa ameríndia que é compartilhada, mas o nível de reducionismo necessário para elaborar modelos comparativos é um preço muito alto para os resultados obtidos. Deixo-o melhor para outros.

Campos: Por que decidiu fazer a passagem dos Matis para os Chacobo?

PE: Existem motivos objetivos e motivos acadêmicos. Tinha voltado aos Matis em 1988 para uma curta visita, sem autorização formal da FUNAl, mas com uma carta de Sidney Possuelo. Porém, não foi suficiente e não consegui ficar com eles. Em 1988, com a nova Constituição brasileira e o Projeto Calha Norte era quase impossível conseguir uma autorização para voltar aos Matis. O Peru estava totalmente fechado por causa de Sendero Luminoso e só restava ir à Bolívia. Na realidade, a maioria dos pesquisadores da minha idade e um pouco mais novos que queriam fazer trabalho de campo nessa parte do mundo na década de 90 foram para Bolívia. Tinham sido feitas poucas pesquisas lá. Por outro lado, estava muito interessado em conhecer a família pano de ambos os lados: os setentrionais e os meridionais. Tinha bastante interesse em trabalhar com um grupo que tinha tido contato durante mais de um século com os brancos, os carayanas, como dizem os Chacobo, para contrastar com os Matis recém contatados. Tinha interesse nos Chacobo. Conversei a respeito com Descola, enquanto tomávamos uma cerveja, mas era apenas uma ideia. Depois recebi a oferta da parte de Scott Atran de ir fazer o pós-doutorado na Guatemala, mas as condições não eram boas: tinha que ficar seis meses ao ano em campo e me pagariam esse seis meses, enquanto a esposa do pesquisador principal, que apenas ficaria três meses em campo, iria receber pelo ano todo. Fiquei lendo sobre os Maias durante uma semana, mas ao mesmo tempo queria continuar trabalhando com os Pano. Estava totalmente louco pelos Pano, a ponto de que me ofereceram um emprego em Orstom (atual IRD), mas durante a entrevista me disseram: "sabe que deverá ir para África porque mudamos o projeto, não é possível ir para América Latina. Está interessado?". Respondi que não. Era estúpido porque poderia ter aceitado e depois de seis meses na África fazer aquilo do que estava a fim, mas não. Daí, quase fui à Guatemala trabalhar com os Itzá. Porém, Descola soube disso, me ligou e disse: "se você quiser, posso apoiar sua candidatura para uma bolsa no Instituto Francês de Estudos Andinos (IFEA) para você continuar na Amazônia". Não sei como teria sido a minha carreira... teria sido diferente, com certeza. E não estaria aqui com vocês. 
Campos: O trabalho de campo com os Matis e com os Chacobo deve ter sido muito diferente.

PE: Bom, escrevi o texto sobre as saudações ${ }^{7}$ precisamente porque existe um contraste entre ambos os grupos. A primeira vez que cheguei com a minha família nos Chacobo, em contraste com os Matis, havia um total silêncio. Demoramos pouco tempo em chegar, de caminhonete, porque fica mais perto da cidade, a uns 120 quilômetros. Chegamos, deixamos a bagagem no campo de futebol, alguém veio e nos entregou uma chave: “bom, lá está a casa, podem deixar as suas coisas", e pronto (risos). "O que vamos fazer aqui?", pensávamos. "Eles não têm o mais mínimo interesse em nossa presença". Algumas horas depois veio um homem mais ou menos jovem, Hërë, que naquele tempo devia ter uns 30 anos. Convidou-me para sentar com ele e quis fazer uma entrevista: "o que você quer saber?". Enfim, a entrevista durou aproximadamente quatro minutos. Isso foi em 1991. Depois de dois meses, mais ou menos, os Chacobo disseram a Hélène: “Você está aqui com as crianças e você trabalha, mas o Felipe... está de férias?" (risos). Eles não entendiam. Mas depois de mais alguns meses começaram a entender que tinha outra forma de trabalhar, e acho que perceberam que eu estava aprendendo coisas. Um deles me fez o melhor cumprimento que recebi na minha vida ao me dizer: "você é um tipo de antropólogo diferente...", e, bom, fiquei muito orgulhoso. É porque eles tinham visto muitos antropólogos, bolivianos principalmente, que não ficavam sequer uma semana, apenas dois ou três dias fazendo perguntas, ou entrevistas usando um roteiro de perguntas. Não era o meu caso. Durante muitos anos tive essa ideia da pureza - o que é uma loucura e acho que não deve ser recomendado -, de não pedir, de ficar atento. Obviamente podiam ser feitas perguntas, mas não queria que fossem muito dirigidas. Agora não, mudei porque quando vou para fazer pesquisa de campo fico menos tempo e vou com uma ideia mais nítida do que eu quero saber. Agora também falo muito melhor do que o fazia no início. Outra coisa que mudou, não tanto em referência aos Matis, mas sim aos Chacobo, é a logística. Antes tudo era muito complicado: no primeiro ano, entre os Matis, não tínhamos pilhas, gravador, nada. Era tudo desse jeito, sem lanterna... Uma antropologia ao estilo dos bisavôs. A única coisa que tínhamos era uma máquina fotográfica, mas ficou na mochila seis meses porque os Matis tinham tido experiências ruins, com Cousteau particularmente, e no início não queriam ser fotografados. Apenas depois de seis meses conseguimos começar a fotografar um pouco. E depois, eles nos pediam que os fotografássemos em família, já que sempre lhes retornávamos as fotos que tirávamos!

\section{Campos: Quais diferenças você encontrou entre os Matis e os Chacobo?}

PE: Tudo. Acho que larguei a panologia depois de ter conhecido os Chacobo, porque é quase como se pudesse dizer que os Chacobo não são pano. Dei-me conta de que para entender os Chacobo tinha que conhecer Mojos, em particular, e também olhar mais para o Sul. Parece-me, por exemplo, que, para entender os Chacobo, a etnografia Shipibo é menos útil do que a etnografia Cayubaba, Cavineña, Tacana... Ficamos dois anos na Bolívia, e, no total, passei em torno de dezessete meses em campo com os Chacobo, o que é bastante tempo. Mas não publiquei nada, ou quase nada, porque tinha tantos materiais matis que acabei dedicando a maior parte do meu tempo à etnografia 
matis. Precisei conseguir um emprego e fazer as coisas que um acadêmico faz, e por causa disso não tive tempo para aprofundar e fazer as leituras necessárias para aproveitar bem o que sei sobre os Chacobo. Porque eu posso escrever sobre os Matis quase de olhos fechados, mas não sobre os Chacobo. Não fiz com o material sobre eles aquilo que se faz para o trabalho de tese, no que se refere à exploração dos dados de campo. Não sei exatamente. É por isso que estou querendo fazer trabalho de campo novamente. Vou ficar seis meses a partir de fevereiro e lograr, finalmente, algo mais sólido, porque é uma lástima ter investido tanto tempo e não fazer nada com isso ${ }^{8}$.

Por exemplo, o primeiro texto que escrevi sobre os Chacobo um tempo atrás foi porque Diego e Lorena me mandavam mensagens a cada dia perguntando sobre a onomástica, e cansei um pouco de ficar respondendo (risos). Não é isso, na realidade tinha os materiais e escrevi um artigo, assim que graças a eles finalmente escrevi alguma coisa sobre os Chacobo. Porém, o artigo não é tão bom assim porque parti do modelo matis como se fosse o mais normal, o mais natural no mundo, para, a partir daí, explicar porque os Chacobo são diferentes. Enfim, isso não faz muito sentido?.

Campos: Mas a onomástica chacobo não é tão diferente da dos Katukina, ou sim?

PE: Acho que os Kaxinawá, e os Matis têm uma onomástica bastante parecida.

Campos: Mas a onomástica dos Katukina é mais parecida a dos Chacobo que àquela dos Kaxinawa.

PE: Vocês acham? Enfim, então preciso revisar as minhas opiniões sobre os Chacobo em relação aos outros Pano. Tenho ainda uma quantidade enorme de dados inéditos sobre a onomástica chacobo, e seria o caso de retomar esse dossiê nos próximos anos. Tenho também uma quantidade enorme de dados sobre as bebidas fermentadas, que espero publicar nos próximos anos.

Campos: Você repensou alguma coisa dos Matis à luz dos dados chacobo, ou vice-versa? Quiçá você naturalizava alguma coisa olhando-os com "olhos chacobo" ou com "olhos matis", e o fato de ter trabalhado com ambos os grupos permitiu repensá-los em termos de contraste.

PE: Ah! Aprender Chacobo me permitiu entender melhor os Marubo e os cantos antigos dos Matis, que eram mais parecidos ao pano padrão. Percebi que algumas coisas que para mim eram inicialmente palavras estranhas eram muito parecidas ao chacobo; isto me ajudou um pouco. Ou também detalhes da vida cotidiana, como a importância do casal entre os Chacobo que não se manifesta da mesma forma entre os Matis. Por exemplo, os casais Chacobo vão tomar banho juntos; diferentemente, entre os Matis os homens iam em grupo e as mulheres o faziam à parte. Dou-me conta do significativo da forma de agir dos Matis, pelo menos em certa medida, pelo contraste com os Chacobo. Não aprendi tanto sobre os Matis, mas o que aprendi acho que está certo e não quero mudar a minha etnografia. Nesse sentido, os Chacobo não tiveram tanta influência. Cometi alguns erros, sim. $\mathrm{Na}$ minha tese tem várias coisas que são obviamente erradas. Mas percebi isso voltando ao campo com os Matis 
e não com os Chacobo. E ainda, depois do primeiro trabalho de campo com os Chacobo, não fiz nada de muito inovador em relação aos Matis. Passei muito tempo fazendo outras coisas e aprimorando o material, e fiz vários filmes que me deram a oportunidade de voltar aos Matis ${ }^{10}$. Obviamente se tivesse a oportunidade de voltar por dois anos para realizar pesquisa com os Matis, hoje em dia, seria muito interessante para mim, pelas mudanças que aconteceram com eles.

Campos: Você acha que agora não haveria mais oportunidade de trabalhar com os Matis? É por conta da mudança da situação em termos políticos?

PE: Enfim, isto é muito anedótico, mas há cinco anos estou me dedicando a questões administrativas e virei uma máquina de escrever relatórios e avaliações, e de orientar, de forma que quase não consegui trabalhar, no sentido intelectual, durante esse tempo. Eu pensava que o governo francês ia me liberar por dois anos e tinha o projeto de voltar com os Matis, porque a situação tinha mudado totalmente: existe uma nova geração. Antes não eram bilíngues e apenas tinha um homem que falava duzentas palavras de português. Agora tem rapazes trilíngues que falam perfeitamente marubo, matis e português. Mesmo que seu português não seja perfeito, é excelente e a população duplicou. Da minha parte fiz muito trabalho de transcrição; progredi muito em matis mesmo sem trabalhar como antropólogo, senão como tradutor. Mas a situação ideal seria voltar para visitá-los vinte e cinco anos depois em melhores condições, com tradutores, gravadoras, e com um conhecimento da Amazônia, da literatura, da língua muito mais ampliado, e fazer um bom trabalho sobre o tema das escalas demográficas. Porque quase não me dei conta disso quando comecei, mas agora me parece cada vez mais óbvio que as instituições dos povos com os quais todos nós trabalhamos são amplas demais para a população que existe efetivamente, e esse jogo de escala poderia revitalizar toda a etnografia. Refiro-me a comprovar os efeitos demográficos sobre o que seja. É óbvio que os Matis têm instituições que herdaram dos tempos antigos e que hoje estão superdimensionadas em relação ao tamanho efetivo de sua população atual. Por exemplo, os traços de dualismo e as seções matrimoniais para um punhado de indivíduos; os restos dos grandes rituais, antigamente intercomunitários, mas nos quais, hoje, os convidados são os vizinhos imediatos; etc. Uma sociedade reduzida a uma centena de pessoas, em sua maior parte crianças, verá, inevitavelmente, como suas instituições e valores mudam! Mostrei, na minha tese, o modo pelo qual os ajustes exigidos pela depopulação haviam, inclusive, modificado a terminologia de parentesco, mas penso que seria interessante voltar nossa atenção, do mesmo modo, para o impacto do fator demográfico sobre a cosmologia, os rituais, etc. A questão das mudanças de escala me interessa há muito tempo, e é uma questão que eu me colocava já a propósito das comparações entre Tupinambá e Araweté. A própria ideia de "alteridade constituinte", o sentimento de incompletude ontológica, a famosa "abertura ao outro" lévi-straussiana talvez não seja mais que uma consequência da depopulação causada pelo choque epidemiológico do que uma propriedade intrínseca das cosmologias amazônicas como temos todos tendido a pensar desde muitos anos. Mas para retomar esse dossiê seriamente a partir de um reexame detalhado da etnologia matis, como gostaria de fazer, teria que ter boas condições e um mínimo de dois anos de liberdade, não é? Enfim, não consegui isso, mas sim seis meses 
para visitar os Chacobo, para recarregar minhas baterias "bolivianistas".. É mais viável do que fazê-lo entre os Matis porque estes se encontram numa região muito remota, e a burocracia é também muito pesada, de forma que se exige ter muito tempo. Diferentemente, entre os Chacobo é possível ir muito rapidamente: já compramos as passagens a Porto Velho, e de Porto Velho para chegar aos Chacobo, do outro lado da fronteira, não demora nem dois dias. Dá quase para chegar no mesmo dia.

Campos: Voltando para a possibilidade de analisar comparativamente a família pano e, apesar de que não seja possível ficar acompanhando tudo de novo que se produz, tem certamente intuições iniciais que devam ser mantidas, outras são insustentáveis à luz dos novos dados depois de 25 anos?

PE: Não sei, os trabalhos de David Fleck, por exemplo, abrem caminhos incríveis. O que li nesses últimos anos que mais mudou meu ponto de vista são os trabalhos sobre os Kanamari, porque o ritual matis que fiquei rastrejando, me parece que vem dos Kanamari. As máscaras mariwin, que analisei a partir de uma ótica panológica, deveriam ser reexaminadas à luz do que se sabe hoje sobre a noção de amizade formal (os tawari) e sobre o ritual de celebração intercomunitária (o hori) dos Kanamari. Comecei timidamente ${ }^{11}$, mas seria preciso reler toda a etnografia matis à luz dos excelentes trabalhos que recentemente apareceram sobre os Katukina, como aqueles de Jeremy Deturche e Luiz Costa. A propósito, houve um ano em que um jovem matis se divertia me chamando "Kiripi Luiz Costa ", e não compreendi até muito depois que era o nome de outro antropólogo que ele deve ter conhecido.

Campos: Justamente esse tipo de achado convida a pensar mais em termos de áreas culturais do que em termos de uma lógica etnolinguística pano.

PE: Nesse sentido admito que o que fiz nos anos 80 era de uma outra época.

Campos: Mas você acha que, em termos culturais, existe uma unidade pano?

PE: Enfim, é necessário estabelecer fronteiras; para uma tese não é possível ler tudo e a natureza não é a mesma quando se tem 25 anos... E ainda, os dados não estavam disponíveis nos anos 80 e 90, de forma que...

Campos: É por isso que estamos perguntando sobre as pesquisas atuais.

PE: Enfim, pode ser que estivesse errado em certas coisas, mas não vou admiti-lo aqui. Já que estão preparando um obituário, vamos incluir apenas as coisas positivas, não é? (risos).

Campos: Passado todo esse tempo, da mesma forma que Patrick Menget aconselhou você a levar miçangas para o campo, o que você diria a seus alunos?

PE: A situação mudou tanto. Em primeiro lugar, a maior parte dos alunos já viajou; agora é muito mais fácil. Para ir aos Matis, eu levaria mosquiteiro (risos). 
Campos: Pensando nessas mudanças que você está comentando, como você vê hoje a questão das metades entre os Pano? É um tema que dividiu os panólogos entre aqueles que encontravam metades e aqueles que não, que preferiam modelos mais históricos.

PE: Mas entre os Chacobo não tem sequer traços, não é? Penso que na minha tese procurava metades por toda parte e, na realidade, já perdi o interesse no assunto. Na tese era uma questão um tanto hipotética porque os Matis eram 117 pessoas, a maior parte crianças, de forma que para os 25 adultos haveria uma metade de 12 e outra de $13 \ldots$

Campos: Como tudo, depende dos dados. Porque uma questão é a postulação estruturalista de metades e uma outra quando não tem nada definido, mas sim algumas regularidades. O que chama a atenção nos estudos pano é que as metades não tem nada a ver com os estudos genealógicos. Quase toda a literatura canônica não está baseada em dados estatísticos, mas em modelos, de forma que se discutem modelos e terminologias mais do que regularidades concretas na praxe ritual, matrimonial, política etc. Mesmo Townsley mudou a forma de conceber as metades yaminawa: no início as relacionava com o parentesco e depois as concebeu como um sistema classificatório.

PE: Townsley começou um ano antes de mim, e o encontrei pela primeira vez num simpósio franco-inglês que fizemos em Azay-le-Ferron. Escutei a apresentação dele e fiquei assustado porque eu ainda não tinha publicado nada, mas eram os mesmos dados. Pensei: "estou no mesmo caminho, então não devo estar tão errado, não é?". Mas, para responder a pergunta, tem uma coisa que me impressionou muito nos últimos anos que é a tese de Javier Ruedas: acho que não é possível falar em metades da mesma forma depois de ler esse trabalho. Notadamente porque ele mostra, a partir de seus dados marubo, que os sistemas kariera resultam mais de estratégias políticas que da inércia própria dos modelos de organização social (à la Kaxinawá). Mas a questão do dualismo se põe somente para os Pano do centro e do Norte ; a situação é radicalmente diferente pra os Shipibo e para os Pano meridionais, entre os quais nao parece existir sequer traços de dualismo. Dito isso, eu não fiz o trabalho de análise exaustiva das relações de parentesco que Lorena fez entre os Chacobo. Não o fiz porque quando vivemos entre os Chacobo estávamos com duas crianças, de dois e quatro anos, cujos cuidados davam muito trabalho, e ainda tinha uma etnobotânica e um geógrafo. E depois começamos um projeto multidisciplinar, com um linguista que esteve lá por pouco tempo e também com um etnomusicólogo. Não eram férias, mas não tinha a pressão de escrever uma tese, de forma que a meta era aprender Chacobo, estar lá. Fiz um censo e outras coisas, mas não coletei dados de parentesco. De todo modo, o dualismo não me parece de qualquer utilidade para interpretar os dados chacobo, enquanto me parece ainda hoje fundamental para compreender os Matis.

Campos: Que importância tem para a discussão comparativa sobre os Pano sua experiência com os Kaxinawa? E ainda, extremando a comparação, teve algum efeito a sua pesquisa sobre a indústria nos seus trabalhos sobre os Pano? Tratando-se de um amazonista, parece algo bastante inédito. 
PE: Não sei se é tão original assim porque tem muitos antropólogos que tem um campo exótico e que também fazem trabalhos aplicados. No meu caso não tem nada a ver. São coisas que fiz às vezes por dinheiro, às vezes para descansar ou para conhecer alguma coisa, dependendo de cada etapa da minha vida. E são momentos que têm sido muito importantes na minha trajetória pessoal, porque tive a oportunidade de trabalhar numa empresa como operário e conviver com pessoas que são diferentes, que falam a mesma língua, mas que têm vidas diferentes. Às vezes mantenho reflexos de antropólogo e fico no modo "pesquisador de campo". Lá nas fábricas tinha lembranças dos Matis, dos Chacobo, porque as estratégias de pesquisa eram as mesmas: fazer anotações de pesquisa sem ser percebido, ou fazer alguma bobagem para conseguir informação. Essas questões são as mesmas quando trabalhei na Inglaterra, nos Estados Unidos, na França, e é o que fazia na Amazônia. Escrevi um pequeno trabalho sobre a ornamentação corporal nas fábricas de ferro na França que era, obviamente, um reflexo de panólogo: os ornamentos Matis comparados com o capacete decorado. Mas fora isso a experiência foi totalmente diferente, porque esses trabalhos foram realizados para empresas e não para a universidade. Também são condições totalmente diferentes. Tem pouco tempo para escrever e para ler: se trata de fazer uma entrevista, ficar dois meses em campo numa empresa e escrever o que dá.

\section{Campos: E os Kaxinawa?}

PE: Outro mundo, os Kaxinawá. Foi o trabalho de campo mais curto que vocês possam imaginar: fiquei lá em torno de 15 dias. Mas duas semanas com Eliane Camargo valem o mesmo que seis meses! (risos) E fui recebido pelos Kaxinawa como um rei, porque Eliane trabalha com eles há mais de vinte anos, conhece todo mundo e viu nascer todas aquelas crianças. Ela me apresentou como seu irmão mais velho e seu chefe! (risos). Assim que todos os velhinhos desciam da rede para me recepcionar e me davam comida. E a comida do Kaxinawa... os Matis fervem a carne, as bananas, um pouco de farinha e pronto, porque sequer têm sal; pelo menos não tinham, agora mudou. A comida matis é muito gostosa, mas muito simples. Entretanto, os Kaxinawa preparam os alimentos com ervas e sal, fazem coisas muito sofisticadas misturando banana e amendoim com vários pedaços de carne. Vocês já conhecem? Não sei se foi o fato de ter trabalhado com Eliane, mas podia fazer qualquer pergunta e respondiam assim: "e você pode nos contar como comia seu filho nos anos ' 50 ", e uma velinha respondia: "ah, é, já te contei tudo, mas vou contar a você novamente", e falava. Acho que foi porque me fiz passar por antropólogo parasita, porque Eliane tem muitos materiais etnográficos que não aproveita para se dedicar mais à linguística, e eu estou com vontade de trabalhar com ela e escrever também sobre os Kaxinawa. Mas tenho apenas uma vida e é muita coisa. Está me faltando tempo, mas tomara que algum dia façamos alguma coisa juntos. Dito isso, quando estive entre os Kaxinawá, o essencial de minha obra panológica já estava estabelecido há muito tempo.

Campos: Se pensarmos, por exemplo, na experiência de trabalhar com os Yawanawa e os Yaminawa, essa mudança oferece uma perspectiva diferente. $\mathrm{O}$ aprendido com uns nos permite voltar a situar a experiência com os outros. Nesse sentido deve ter sido interessante o triângulo matis-kaxinawa-chacobo, que permite ter uma imagem pano absolutamente privilegiada. 
PE: O que me falta são os Shipibo, mas, enfim, na realidade, mais do que conhecer novos grupos o que gostaria é um pouco de tempo para trabalhar o material que já possuo. Sempre tem pessoas do mundo todo que me escrevem para dizer: quero escrever uma tese sobre pano, aonde posso ir? E nunca posso responder. Depende de tantos fatores! Na realidade o trabalho de campo com os kaxinawa tem sido o mais agradável de todos, mas foi em condições excepcionais. Por isso, não tenho a impressão de conhecer muito os Kaxinawa. O pouco que vi não serve de grande coisa em comparação com o material que é possível ler. Não tenho experiência com os kaxinawa, não tenho a pretensão de ser um especialista. Mas o estranho

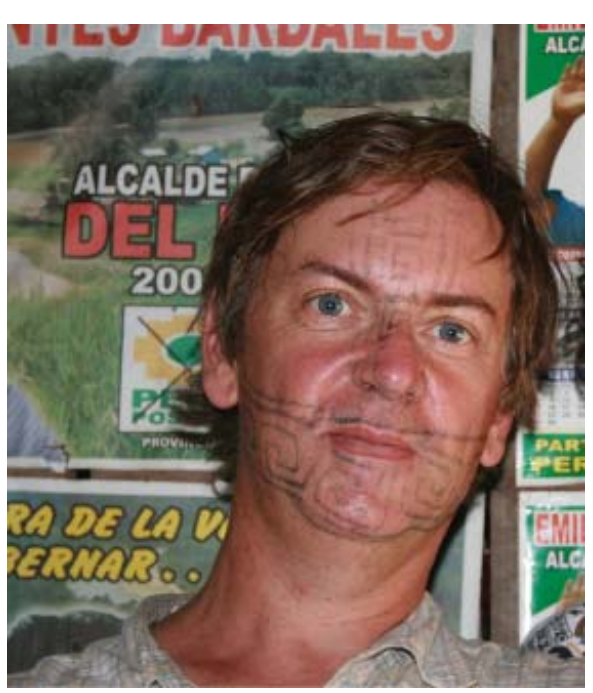

Entre os Kaxinawa, em 2007. Foto de Eliane Camargo. é que depois conversei com os Sharanawa e a comunicação era muito mais difícil do que com os Kaxinawa. Não sei por que, possivelmente por questões linguísticas. As raras vezes em que tive a oportunidade de me encontrar com os Marubo, também achei a experiência bastante enriquecedora - mas trata-se certamente de pequenas experiências de etnografia-express.

Campos: Quais você acha que seriam as contribuições da panologia para o estudo dos povos amazônicos? Seu trabalho, os de Townsley e Kensinger...

PE: Essa é uma pergunta a ser feita para outros, por que os panólogos não são muito teóricos.

Campos: Por que você acha? É uma propriedade do objeto?

PE: Não, obviamente não. É porque também não somos tantos assim. Não sei, acho, por exemplo, que no trabalho de Descola parece, sim, que são os próprios Achuar que o levam à teoria. Ou a tupinologia, que dá como resultado algo intrinsecamente ligado ao trabalho de Eduardo Viveiros de Castro e Carlos Fausto. Porém, algo especificamente pano, não sei, não tem. Credita-se frequentemente a mim a invenção da "alteridade constituinte", mas faz-se isso sem dizer que não fiz mais do que colocar uma etiqueta sobre um fenômeno que observei entre os Pano, mas que já tinha sido descrito por outros a partir de outros campos.

$\mathrm{Na}$ etnografia dos anos 70, os Pano eram praticamente desconhecidos e agora sabemos alguma coisa. Falta alguma coisa de Kaxarari, alguns pontinhos, faltam os Pacaguara. Parece-me uma contribuição ao debate geral. É muito óbvio o que vou dizer, mas eu acho que a pesquisa se realiza por ondas, ou seja, por gerações, e dentro de cada uma dessas ondas todos trabalham as mesmas coisas ao mesmo tempo. Nos anos 80 muitos se dedicaram à panologia; antes disso era o Noroeste, antes ainda, eram os Jê. Agora não: tem teses sobre grupos de toda a Amazônia sendo feitas ao mesmo tempo. A quantidade de trabalhos tem aumentado de forma incrível. Fiz um 
catálogo de tudo o que existia até os anos 90 mais ou menos e dava para acompanhar; agora não dá mais. Tem uma explosão de trabalhos. Para a Amazônia em geral, até o fim dos anos setenta, se defendia menos de dez teses por ano no mundo inteiro, com todas as disciplinas confundidas. A partir dos anos 80 , apareceram aproximadamente umas trinta por ano. E no começo do século XXI, quando eu parei de contar, se tinha mais de 55 teses por ano! E em termos qualitativos também é impressionante a diferença. Tem muito a ver com o fato de que se tem cada vez mais indígenas bilíngues que podem ajudar os antropólogos, que já chegam mais formados. Eu vejo o trabalho de Pierre Déléage sobre os Sharanawa, e era impossível fazer algo tão refinado vinte anos atrás. Ou, enfim, era possível, mas ninguém o fez. É maravilhoso poder ter acesso a todos esses trabalhos.

Campos: E falando sobre os trabalhos, você não atualizou mais a bibliografia pano? Ainda continua com esse projeto?

PE: Sim, mas o que aconteceu é que faz um tempo um missionário copiou a bibliografia pano e a disponibilizou num site. E procurando na internet, a pessoa sempre chega nesse site e o original desapareceu da esfera virtual. E, enfim, atualizei a bibliografia, mas não a divulguei. Eu tenho esse defeito às vezes: fazer $80 \%$ de um trabalho e depois passar a fazer outra coisa. Enfim, todos somos um pouco assim. Mas se vocês querem fazer uma nova bibliografia pano, eu já estou com os dados, embora não organizados de forma tão sistemática como a anterior, e não sei se vale a pena, também. Era alguma coisa que fiz porque estava escrevendo a tese e pensava que devia saber tudo a respeito da família linguística. Esse foi um conselho que me deu Francisco Queixalos, quando era ainda estudante de mestrado: a primeira coisa a fazer é uma bibliografia exaustiva do domínio estudado. Agora já não acredito tanto assim nas famílias linguísticas e tem muito mais material, de forma que não sei se vale tanto a pena o esforço. Além disso, a internet mudou totalmente a forma de fazer as pesquisas bibliográficas. Fiz também para ajudar outras pessoas que queriam estudar pano. Tem que começar com as perguntas teóricas.

Campos: Naquela divisão clássica nos estudos amazonistas entre a economia simbólica da alteridade, a economia moral da intimidade e a economia política do controle, como você situaria seu próprio trabalho?

PE: Tenho muitos amigos... (risos) Não, falando sério acho que pela minha formação inicial tenho mais afinidades com a escola franco-brasileira do que com a inglesa. E ainda me interesso muito pela etnografia: se posso encontrar etnografia na Escócia, ou seja lá onde for, me interessa bastante. O que não suporto são os trabalhos a priori, dedutivos, muito dogmáticos. Dá para fazer um trabalho de campo sólido e depois usar uma armação teórica, seja qual for. Sei que daqui a cinquenta anos os nossos netos vão rir das bobeiras que pensamos sobre esses temas, mas os dados estão lá.

Campos: Na defesa do seu HDR ${ }^{12}$, algum membro da banca comentou que você escreveu muita etnografia, mas jamais tentou esboçar um modelo pan-amazônico. 
PE: A evidência, a sistematização teórica nao é meu regime de funcionamento científico preferido, e sempre estive bastante preso à ancoragem da pesquisa no concreto. Mas tive sorte. Ao invés de me criticar, Anne-Christine Taylor me comparou com um franco-atirador etnográfico (risos), porque às vezes tem um ponto na teoria que me parece uma bobagem, mas nem por isso crio um debate intelectual. Ela me disse também que: "uma das [minhas] posturas favoritas - e na qual destac[o]- é a de [me] situar à margem de uma "grande teoria "e desinflar alguns argumentos lançando flechas discretas mas impecavelmente dirigidas", de forma que eu desempenharia o papel de um corta-fogos, apegado à precisão etnográfica e, implicitamente, reticente a respeito de qualquer teorização que não seja suficientemente respeitosa com a complexidade e com a resistência dos fatos registrados. Eu poderia, sem dúvida, propor meus próprios modelos de largo porque possuo bastante experiência de campo e li muita antropologia. Porém, fazer um modelo próprio... tentei fazê-lo com os animais e foi uma experiência interessante. De fato, acho que esse trabalho ${ }^{13}$, escrito antes de sequer botar o pé na América Latina, tem sido o mais citado dos meus escritos, mas perdi o interesse. E Anne-Christine obviamente adora os modelos. Contudo, vocês preferem que nos próximos dez ou quinze anos me dedique a fazer outra proposta sobre o animismo ou o perspectivismo, ou a escrever uma etnografia sobre os Chacobo? O que vocês acham mais interessante? Por que meus leitores estão todos aqui, não é? (risos).

Campos: Ao mesmo tempo não é exagerado afirmar que não tem panólogo que não passe pelos trabalhos de Philippe Erikson, o qual confirma a relevância etnográfica do seu trabalho.

PE: É. Meu trabalho era estruturalista também, mas não o é mais. Obviamente porque se passou mais de um quarto de século e tem coisas que atualmente não afirmaria. Por exemplo, as proposições um tanto gerais sobre a alteridade que refletem, por assim dizer, uma influência da "tupinologia panologizada". Obviamente os dados que possuo sobre esse fascínio pelo outro e sobre as metades surgem no campo. Mas possivelmente reifiquei um pouco esse aspecto insistindo demais sobre a alteridade constituinte. E todos dizem que ia atrás das palavras, mas a ideia já existia e a aprendi na universidade com os meus professores, obviamente. Não sei se o diria da mesma forma hoje em dia. Estava à procura de aspectos mais estruturais e agora, como todos os antropólogos, estou mais interessado em elementos mais fenomenológicos, numa sociologia mais dinâmica e menos formal. Mas é também um efeito da moda.

Campos: O "pode ser" da própria etnografia... Porque é muito interessante o fato de que tenha feito seus trabalhos mais teóricos antes de ir para o campo, e depois a própria etnografia levasse você a outra forma de praticar a antropologia. Ou seja, que além das modas teóricas provavelmente a experiência etnográfica influi nessa mudança.

PE: Não lembro quem foi que me disse há pouco - enfim, lembro, mas não vou dizer o nome - que o que mais Ihe tinha impressionado da minha produção científica foi o texto de 1986 sobre as tatuagens ${ }^{14}$. E fiquei triste, porque é um colega que admiro bastante, mas em minha opinião se trata de um artigo de juventude com uma 
proposta muito ambiciosa que, na realidade, estava baseada em poucos dados empíricos. Nessa proposta trago o canibalismo para os Pano, mas é algo que não é possível averiguar; não é mais do que uma ideia, um jogo intelectual. Diferentemente, do ponto de vista empírico, a proposta mais ambiciosa sobre o papel dos animais de estimação continua, me parece, tendo valor. Nesse trabalho sobre os animais, há uma proposta funcionalista a partir de um argumento baseado na psicologia e claramente se trata de um grave erro de juventude, mas, para além disso, me parece uma observação interessante. Enfim, era também um trabalho de principiante. Sobre a temática dos animais de estimação, eu tinha pensado revisar o estado atual do debate para a defesa do HRD, mas não o fiz porque se falou muito a respeito desse tema. Anne-Christine Taylor me disse também que o trabalho abria caminhos que poderiam ser desenvolvidos posteriormente. Fiz também, por exemplo, um trabalho comparativo sobre a sexualidade amazônica e escrevi um trabalho que ninguém viu ainda sobre os cheiros. Adoro escrever trabalhos desse tipo, de compilação, e dai dá para elaborar uma proposta teórica e globalizante de vez em quando, mas teria que ser algo para fazer com mais tempo de dedicação.

Campos: Mas você prefere ir ao campo.

PE: Sim. Trabalho muito porque adoro trabalhar, mas sou muito preguiçoso na realidade. Enfim, acontece também que o campo nem sempre é o paraíso. Acho que, no campo, os primeiros anos são difíceis, mas depois se travam amizades e as coisas se entendem melhor. Hoje em dia adoro ir, mas não vou dizer que sempre foi o paraíso. Sofri muito no campo, como todo mundo.

Campos: Tem alguma pesquisa realizada em outras regiões do mundo, como os Andes, Mesoamérica, América do Norte, Indonésia ou África pela qual você se interessou especialmente ou que influiu no seu trabalho?

PE: Não li muito sobre outras partes do mundo. Atualmente, nesses últimos anos trabalhando no CNRS como avaliador tive a oportunidade de ler mais. E claro, se tivesse a oportunidade de começar novamente acho que seria importante ter uma cultura antropológica mais universal e não me especializar tanto. Ao mesmo tempo, é importante ter uma base inicial. Sobre os Andes tem, sim, algum trabalho. Quando retornei de Bolívia no ano 1993 com a experiência com os Chacobo, os Matis e ter morado em La Paz por alguns meses, que é uma cidade andina, e por conta do assunto do Inca pano, queria dedicar uma dezena de anos a comparar os Andes e a Amazônia. De fato, essa era a proposta que fiz para entrar no CNRS, mas nunca entrei. Pode ser que houvesse um certo ressentimento: “já que não me deixaram fazer isso, vou fazer outra coisa". Porque trabalhando na universidade, se dispõe de menos tempo para pesquisar do que no CNRS; pelo menos na França, onde é praticamente impossível obter uma licença sabática (em Nanterre, por exemplo, tem-se 8 vagas por ano para aproximadamente 3000 professores). Deixei-o para outro momento e, felizmente, chegaram outras pessoas depois, como Isabelle Daillant ou Vincent Hirtzel, e outros mais novos, que estão fazendo o que eu queria fazer quinze anos atrás. E provavelmente seja melhor, porque para trabalhar nos Andes é preciso passar muito tempo nos arquivos e isso é algo que nunca tentei. 
Campos: Não estava me referindo apenas ao trabalho de campo, mas a possíveis influências na literatura sobre outras regiões para injetar um pouco de ar fresco no debate amazonista, que muitas vezes acaba repetindo os mesmos argumentos.

PE: Esse é precisamente o comentário que faço para mim mesmo ao menos uma vez por mês. Estou com um monte, pilhas e pilhas de livros que não li, que comprei, mas não li, sobre a Amazônia. Gosto muito de ler sobre essa matéria. Mas como estão dizendo, é sempre a mesma coisa e o conheço há 25 anos. Por que sinto o fascínio de ler o último livro sobre a Amazônia? Quiçá porque na realidade não sei o que escolher da literatura africanista. Por isso, gosto muito de fazer esse trabalho de avaliação. O CNRS solicitava que avaliasse uma tese sobre os médicos em Camboja, por exemplo, ou sobre a percepção do risco vulcânico na Polinésia, por exemplo. Assim, sem necessidade de escolher, é um pouco ao azar que guio as escolhas e tem-se às vezes boas surpresas. Não sei por que não tenho tempo, não tenho a oportunidade, mas obviamente seria uma abertura. E uma parte do trabalho são também os contatos, as relações humanas, e existe a expectativa de que um amazonista deve conhecer o que foi publicado: se vai num congresso deve poder falar sobre tal ou qual livro. E o tempo passa rápido e não tem muito tempo para África ou Ásia. Mas se você tem uma lista... (risos). Li coisas sobre a América do Norte, mas não é possível ler tudo. É uma colocação que fiz a mim mesmo quando trabalhei em Sandersville, Georgia. Passei quatro meses lá. Uma das coisas que adorei é que o mundo é amplo e não dá para conhecer tudo. E todos vão para Veneza ou São Paulo, mas, quem vai para Sandersville? Ofereceram-me a oportunidade de passar uma parte da minha vida nesse recanto perdido do sul de América do Norte. Depois vou ler alguma coisa sobre África, por acaso, e irei incorporá-lo a minhas experiências, e, quem sabe, me dê alguma ideia, me ajudará com os Chacobo. Mas não é alguma coisa que faça de forma sistemática. Infelizmente, isso depende das capacidades de leitura que tem cada um. Tenho três filhos, uma casa grande e também a minha preguiça.

Campos: Na sua defesa de HDR perguntaram como você se situaria nesse debate permanente que existe entre Descola e Viveiros de Castro e a sua resposta foi que você é uma espécie de antídoto. Em que sentido?

PE: Foi no contexto de uma outra pergunta: por que eu não me dedicava mais aos modelos teóricos? Eu respondi que havia algumas poucas pessoas que o tinham tentado com bastante sucesso e que com isso bastava. Cada um deve reconhecer os próprios limites. Acho que tem alguns estudos que se fazem com o perspectivismo na cabeça e que obscurecem os dados mais do que iluminá-los. Os modelos teóricos não estão feitos para ajudar a descobrir fatos no campo; trata-se antes de um trabalho de síntese. E o reducionismo implicado nos modelos teóricos, que é necessário, me assusta um tanto também. Em certa medida, tem coisas que podem ser aceitas hoje em dia porque já foram propostas. No ano 1983 propus a tese de que o tratamento dos animais de estimação na Amazônia é de tipo filial, implicando laços de parentesco e um forte antropomorfismo, e imaginava o que iam responder os avaliadores: que eu era racista ou que era uma forma de considerar que os indígenas não fazem a distinção entre animais e pessoas. Mas hoje em dia, até as facas falam! E ninguém se impressiona. Mas nos anos 
80 era algo difícil de dizer para alguém jovem. E ao mesmo tempo me parecia óbvio, ao ler as monografias, que tinha algo nas relações com os animais que era similar às relações entre humanos. A distinção não é tão marcada, porque os xerimbabos são como filhos, mas, ao mesmo tempo, podem ser mortos: diz-se que não se pode, mas se faz. E para elaborar um modelo é preciso dizer: "são pessoas". Segundo Anne-Christine a tese tinha um fundo naturalista e pode ser que tenha razão também.

Campos: Também pode ser um posicionamento pessoal com implicações teórico-metodológicas: é possível extrair importantes implicações da etnografia sem se deixar tomar por modelos apriorísticos nem reduzir os dados. Os modelos teóricos são uma espécie de síntese, e talvez não tenha muito sentido tratar de aplicá-los à etnografia como se fosse um molde.

PE: Talvez seja apenas um pretexto, mas estou com pouca disponibilidade de tempo e mental para fazer trabalhos de fôlego. E quando estou com tempo durante o verão, frequentemente vou fazer trabalho de campo, assim é por isso, acho, que produzo mais artigos e menos modelos ambiciosos. Ou seja, vou ter quinze dias para escrever e não dá para produzir livros: pelo menos, não eu. Todo mundo diz que publico muito, mas não é assim; sinto que me falta tempo para fazê-lo bem. Dividido em 25 anos, o total das minhas publicações é constante. Contudo, cheguei num ponto da minha carreira em que estou com a impressão de que não tenho mais nada novo a dizer. É claro que posso fazer avaliações, comentários, tentar realizar sínteses de vários temas, mas não sem voltar ao campo. Agora, por exemplo, posso trabalhar com Eliane aproveitando seus dados de campo, isso seria valioso. Quando trabalhei com os Chacobo meu único projeto era ter uma base sólida para algum dia poder fazer um trabalho. Passei dois anos sem nenhuma proposta concreta exceto conhecer alguma coisa sobre bebidas alcoólicas, a chicha; mas era também uma comparação com os Matis. Embora os Matis não tenham nenhuma bebida fermentada, tem um papel ritual importante. Vocês já sabem porque o leram. E é óbvio que trabalhando com os Chacobo tem alguma coisa a dizer sobre a chicha porque é fundamental, porque é o que fazem o tempo todo; porque acordam às quatro da manhã para tomar chicha. Tem chicha quase todos os dias. Quando acaba, vão procurar onde tem mais. Lembrei agora de outra anedota, voltando à questão sobre as etapas importantes do trabalho de campo. Entre os Chacobo tudo mudou quando começamos a fazer chicha em casa, quando fiz uma plantação de mandioca com um mestre bilíngue e partilhamos um roçado de dois hectares. A minha esposa começou fazer chicha; tinha aprendido fazendo chicha com as outras mulheres e começou a fazer nossa própria chicha com nosso milho. A primeira vez foi para o meu aniversário, como pretexto oficial para convidar alguns vizinhos para beber. Beberam chicha com um certo incômodo, porque era a chicha de uma branca e não sabiam se iriam ou não se contaminar. Era algo muito esquisito porque os brancos não tomam chicha e lá estava Hélène oferecendo-a. Bebiam-na com muita seriedade, não como costumam tomá-la, senão do mesmo jeito que bebem café: tomavam um pouco e me parabenizavam: "Feliz aniversário, dom Felipe". Foi uma situação muito formal e pesada. Mas na outra semana começou novamente e aos poucos a nossa casa passou a formar parte do circuito da chicha e a qualidade da relação com os Chacobo mudou totalmente. Sem chicha não tem vida social nesse grupo. 
Campos: Uma pergunta muito geral: quais são as suas impressões sobre o panorama da etnologia atual, particularmente a amazônica?

PE: O que mais me impressiona é a qualidade dos trabalhos. O que era publicado no início do século XX e o que se faz hoje em dia não tem nada a ver. Mas não sei muito bem o que responder, porque não tenho uma visão geral da antropologia. Sobre a etnologia amazônica também não sei, porque há quatro ou cinco anos que fiquei um pouco à margem da antropologia amazonista. Em 2004 poderia ter respondido, mas hoje estou com a impressão de estar sobrevivendo, tratando de continuar sendo amazonista e fazer todo o resto. Existe uma multiplicação dos trabalhos que é impressionante. Tem muitos linguistas que trabalham como antropólogos. Não sei se sempre foi assim, mas me parece que hoje em dia quase a metade dos trabalhos é assim. Conheci um ambiente intelectual entre os amazonistas que era muito informal, no qual todo mundo se conhecia e penso que o panorama está se complexificando até o ponto de ser impossível conhecer todo mundo ou ter amizade com a maioria como acontecia naqueles dias. Também não sei se é possível dominar toda a literatura amazonista como o era dez anos atrás. Precisaria meditar durante uma semana para poder responder.

Campos: O que você opina sobre as discussões surgidas a partir do pós-modernismo em relação à escrita etnográfica e ao posicionamento político do antropólogo?

PE: Na França alguns colegas o rejeitam totalmente e eu não me identifico com esse movimento. Obviamente não serei o Tartufo, mas penso que essas ideias não são, quiçá, tão boas assim, no sentido de que sempre tivemos uma atitude crítica sobre as fontes, mas agora está se generalizando. Eu não posso rejeitar totalmente a noção de cultura, por exemplo, me parece que faz bastante sentido. Porém, ao mesmo tempo, é claro que deve se ter em consideração a intersubjetividade. Parece-me óbvio hoje em dia. Quando escrevi a minha tese, como vocês sabem, na introdução falava um pouco sobre as condições do trabalho de campo. Naquela época parecia algo novo e corajoso. Acho que muitos aspectos desse movimento pós-moderno derivam de uma reação contra aquela forma excessivamente fria de fazer antropologia que dominava na época. Enfim, foi pior quando Lévi-Strauss publicou os Tristes Trópicos e Rivet não quis mais falar com ele...

Campos: Quer dizer que Tristes Trópicos poderia ser considerada a primeira etnografia pós-moderna?

PE: Mencionei-o como uma boa piada... Também tem algo disso em Nimuendajú. São poucos os que se identificam como pós-modernos ; é algo como " politiccamente correto " : aplica-se aos outros, jamais a si mesmo. Na França muitos antropólogos são tradicionalistas demais e, consequentemente, rejeitam o qualificativo "pós-moderno". Não concordo com essa atitude fechada de uma parte da antropologia francesa.

Campos: Nesse sentido, pensando na sua conexão com as antropologias de outros países, com outras bibliografias, como se mantém seu diálogo com antropólogos desses outros países por onde você costuma andar ou andou? 
PE: Bem, existe um antes e um depois do e-mail. Tudo mudou enormemente. Tive poucos contatos com o Brasil, na realidade, porque nunca vivi no país como professor visitante. No Brasil sempre vinha fazer trabalho de campo e depois ia embora, mas como tem muitos brasileiros morando na França, e a gente se encontra nos congressos, tive contato com muitas pessoas durante anos. Em relação aos franceses, que constituem uma escola importante, é claro que conheço todo mundo e nos encontramos com frequência. E como a Inglaterra não é muito distante, também mantenho contato com os ingleses. Agora, com os norte-americanos é um tanto estranho, meu pai é norte-americano e tenho família lá. Viajo com frequência aos Estados Unidos, mas tive pouco contato com os colegas de lá, excetuando Ken Kensinger e Bob Carneiro. Agora com a SALSA ${ }^{15}$ estou tendo mais contato com os norte-americanos do que tinha dez anos atrás. Kensinger organizava aquelas reuniões em Bennington e por acaso uns amigos dos meus pais tinham uma casa perto de lá, de forma que pude assistir umas poucas vezes. Acho que fui nessas reuniões três vezes e encontrei-me com antropólogos da costa Leste dos Estados Unidos. Mas o contato que tenho é mais por leituras, porque eu conheço os trabalhos e mais nada. E com peruanos e bolivianos, quase nada, exceto alguns que trabalham na Inglaterra. Pesquisadores bolivianos na Bolívia, sim, mas não existe a tradição de trabalhar nas terras baixas, por exemplo, e conto com bons amigos na Bolívia, mas não antropólogos. Na verdade, não me identifico com nenhuma escola em particular.

Campos: Mas tem autores que tem inspirado você teoricamente?

PE: Patrick Menget me influenciou muito, nem tanto através de seus textos senão através dos seus ensinamentos. Eu ia a sua casa e ele me emprestava livros. Quando comecei na antropologia tinha uma admiração sem limites por Descola. Li a sua tese antes que fosse publicada e o estilo, a forma de escrever, me impressionou bastante quando estava começando na antropologia. Claro que eu tinha sido preparado para ler isso e era um modelo perfeito do que poderia ser um estudo etnográfico. Agora não sei se foi ou não um modelo que tratei de seguir, mas foi uma influência, e como era francês podia entendê-lo perfeitamente. Li Eduardo Viveiros de Castro quando era ainda novo porque sua monografia tinha acabado de aparecer, e fiquei muito impressionado, mas como era em português, quiçá, não me impressionou da mesma forma. Mauss me influenciou também bastante, e Lévi-Strauss nem tanto; pode ser que agora mais. Agora tenho outros interesses como professor para conhecê-lo. Mas acho que quando estudava em Nanterre nos anos 80, já tinha começado a rejeição a Lévi-Strauss, ao estruturalismo do passado e eu o li, mas não gostava do seu estilo. Agora eu gosto mais dele. Vai se mudando o ponto de vista, obviamente. Não sei se dá para publicar isto, mas ao contrário de Lévi-Strauss, o estilo de Descola jovem já não me agrada tanto como quando era novo. Entretanto, compreendo melhor Lévi-Strauss. Mas posso mudar novamente (risos). E o estilo de Mauss, lido em francês é muito bom, mas não sei como pode ser traduzido, porque para compreendê-lo em francês já é uma coisa. É muito intuitivo; escrevia de uma forma muito estranha e um tanto arcaizante. É bastante difícil.

Campos: A sua banca do HDR comparou também a quantidade de resenhas que você fez com aquela que Mauss escreveu. 
PE: Mauss quase se matou escrevendo resenhas, e eu vou seguir o mesmo caminho. Mas tem resenhas e resenhas: algumas são feitas muito rapidamente e outras implicam semanas de trabalho. Fazer uma resenha é como fazer um artigo, procuram-se satisfações comparáveis, salvo que a resenha se faz mais rápido. E também é uma forma de se comunicar: eu tenho alguma coisa a dizer sobre esse livro e quero compartilhá-lo com uma comunidade virtual de amigos, de colegas... Sim, eu gosto bastante de escrever resenhas. Pode-se, além disso, dizer coisas importantes nelas. Ainda por ocasião de meu HDR, Anne-Christine destacou, por exemplo, que possivelmente eu fui o primeiro a ter sublinhado, em uma resenha que saiu em 1988, que a análise das ontologias amazônicas se inclinava, lenta mas firmemente, pelo reconhecimento do "relativismo natural"16.

Campos: Voltando aos Pano, a convivência foi diferente entre os Matis, que eram recém-contatados, e os Chacobo?

PE: Sim, entre os Matis nunca dá para saber se vão ficar bravos; são muito imprevisíveis. Às vezes as coisas vão bem e acontece alguma coisa, não se sabe ao certo o que, e todos ficam mal. Entre os Chacobo não acontece isso, porque sabem o que é um estrangeiro. Entre os Chacobo apenas uma vez tive uma dificuldade. Quando fiz o roçado com o professor, não pedi permissão numa assembleia, assim que depois organizaram uma reunião para me acusar. Mas o homem que me acusava estava quase com vergonha de fazê-lo; o fez por uma questão formal. Eu expliquei e pedi perdão, assim que tudo logo voltou ao normal. Em outra ocasião, os rapazes roubaram a câmara fotográfica e o capitão fez uma grande reunião e logo apareceu a câmara. A convivência com os Chacobo é muito fácil. Entretanto com os Matis até hoje tem uma tensão, ligada à dificuldades de comunicação. Sempre conversei em matis com os Matis, excetuando uma vez eu usei o português para explicar a uns rapazes algo sobre um filme. Mesmo com os que aprenderam português falo em matis, e obviamente meu matis é limitado: entendo mais do que posso falar. Assim que com eles a relação é muito frágil, no limite entre a amizade e o mal-entendido. Lembro uma vez em que um matis tinha vendido para mim uma zarabatana e me deu uma lista de pedidos: queria um terçado, um machado, três facas, roupa e várias outras coisas. Eu comprei tudo, mas faltava uma faca. E ele quase me mata: "pedi três facas e tem apenas duas". Depois percebi que não estava bravo porque faltasse alguma coisa, mas porque era demais. Tinha Ihe dado demais e colocado-o numa situação difícil. O pretexto que achou era que faltava um $1 \%$ do pedido e tudo isso, em matis, é muito difícil. Aprendi a permanecer muito tranquilo. Da mesma forma com os cineastas que queriam ficar na aldeia para filmar, mas os Matis estavam se mudando de lugar porque tinham esgotado todos os recursos daquela área. Todo dia precisava convencê-los para que ficassem mais um pouco e a tensão aumentava a cada dia. Chegou um chefe da cidade e me disse: "um milhão de dólares para filmar". Salvei a situação dizendo que se podia me dizer a quantidade de zeros que tinha um milhão, dar-lheia essa quantidade. Ele continuou. Não sei a razão, mas eu ficava calmo, calmo. No dia seguinte pegaram todas as coisas do técnico de som, porque esse homem não gostava muito de ficar no campo. Ele fez um espetáculo e veio um jovem com arco e flecha dizendo que ia matá-lo. Eu sabia que com arco e flecha não era perigoso, com um terçado ou um pau, sim, mas com flechas era apenas para assustá-lo. As coisas eram muito complicadas, mas não era assim com os Chacobo. 


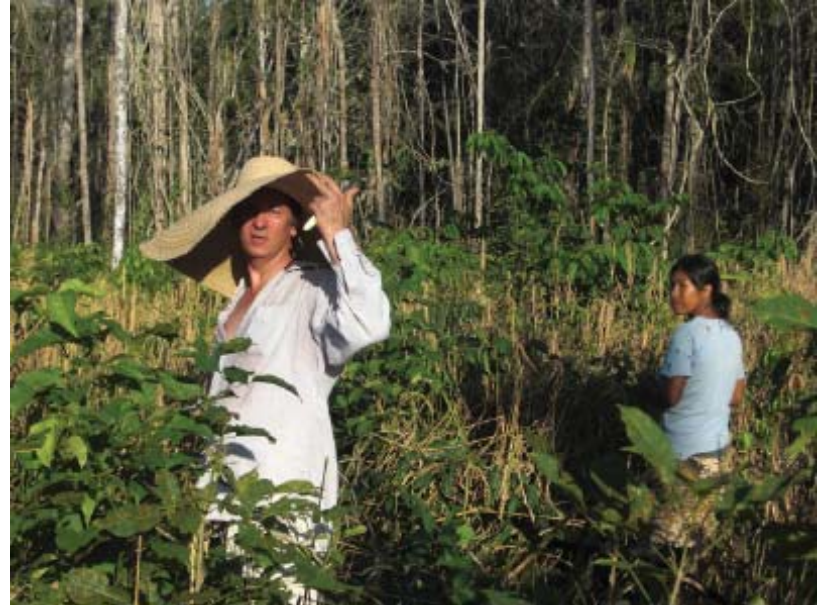

Colheita de arroz com Chacobo, em 2010. Foto de Hélène Erikson

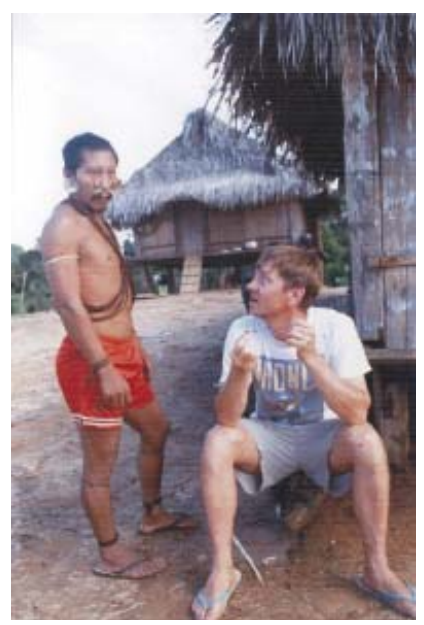

Entre os Matis, em 2001. Foto de Andy Jillings

Campos: E quando bebem chicha, não há violência?

PE: Não comigo. Tem violência quando vão matar um feiticeiro. Depois alguém conta: "colocaram pedaços de taboca no nariz e nas orelhas" ou "o enterraram vivo". Claro que tem violência, mas para os Chacobo, eu sou um antropólogo generoso e bonachão, pai de família, o gringo rico que chega com o apoio da embaixada de França - temos projetos, podemos levar doentes para o hospital... Os Chacobo me chamam "Papa Felipe" e me consideram mais como uma figura paternal. Esse papel já existe entre eles. Várias vezes me pediram seriamente para ficar para sempre entre eles, como missionário! Entretanto, entre os Matis não é assim, porque têm raiva do mundo dos nawas por conta das mortes ${ }^{17}$ e ainda têm poucos interlocutores. Sempre tive a impressão de que quanto mais falo o matis, mais eles podem reclamar e me acusar, a mim ou a Hélène. Nesse sentido foi interessante quando veio Sílvio Cavuscens no campo depois de ter visitado os Kanamarí com Lino Neves que fiz depois um trabalho na UFSC. Vieram os dois, pessoas muito simpáticas, mas provocaram um caos. Dirigiram um discurso aos Matis: "Vocês não devem usar motores, não têm porque usar espingardas porque vão perder suas tradições". E a mim eles disseram: "você chega aqui com comida enlatada. Isso não presta, deve comer apenas mandioca, coisas autênticas". Pode ser que estejam certos, mas acho que não. Quando eles foram embora, os Matis quase nos mataram, porque o que entenderam foi: "vieram seus amigos sovinas e disseram que somos maus, tudo o que fazemos é ruim. Não querem nos dar o que mais precisamos, que são os cartuchos e a gasolina, etc etc.". Mas minha única culpa foi estar presente durante o discurso. Isso acontecia o tempo todo com os Matis. E com os cineastas, é meu papel profissional: estou lá para que eles reclamem comigo e não com os cineastas. O ponto 
positivo é que como duas vezes, uma com os cineastas ingleses (aveias) e outra com os amigos matis (macaxeira), e a conversa é muito divertida em ambos os casos. Mas quando se encontram os Matis e os cineastas, eu estou no meio, e preciso mentir a ambos ou traduzir parcialmente para evitar conflitos.

Campos: No caso dos Yaminawa uma boa parte das mortes por doença é atribuída à feitiçaria, de forma que acusavam outros Yaminawa. Podia existir outro tipo de rancor contra os brancos, mas não nesse sentido. Os Matis tinham consciência de que todas aquelas mortes estavam relacionadas aos brancos?

PE: Da forma que eu o entendo, sim. Culpam em parte as faculdades imediatas do xamanismo, mas é muito nítido o papel dos brancos como fonte secundária das epidemias, como causa. É claro que tem também uma leitura xamânica das epidemias entre os Matis, mas a associação com os brancos é clara ${ }^{18}$. Em relação aos brancos da FUNAl, os Matis dizem: "eles nos atraíram com projetos e depois vieram as epidemias, e vocês nunca vão pagar essa dívida dos mortos, mesmo que seja com milhares e milhares de terçados". Na sua perspectiva sempre devemos mais. Os Chacobo me consideram um milionário, mas os Matis me conheceram como um pobre francês descalço. Ainda assim, todos os nawas estão em dívida infinita com eles. Tem muito a ver com a representação do tempo, dos objetos. Por exemplo, os debates com os cineastas é sobre os filmes, que são considerados eternos, embora os bens sejam temporários: a convivência foi fascinante, mesmo que difícil. O argumento era: "vimos que quando somos filmados, não morremos, mas depois, quando morrermos, o que vai acontecer? Porque tem uma parte viva associada ao filme, e o filme é eterno, mas o que é entregue a nós não é eterno". Fazem essa associação de forma muito marcada, e eu posso repetir incansavelmente "os filmes não são eternos", mas não acreditam no que digo (risos).

Campos: Você sente que os Matis têm muita raiva dos brancos?

PE: Sim. E com razão, não?

Edilene Coffaci de Lima é Doutora em Antropologia Social pelo PPGAS-USP e atualmente professora adjunta no Departamento de Antropologia e PPGAS da UFPR. Desenvolveu seus trabalhos de mestrado e doutorado entre os

Katukina (pano) no Acre.

Lorena Córdoba é Doutora em Antropologia pela Universidad de Buenos Aires, professora na mesma universidade e pesquisadora do CONICET. Realiza pesquisa entre os Chacobo, na Bolívia.

Laura Pérez Gil é Doutora em Antropologia Social pelo PPGAS-UFSC e atualmente é professora adjunta no Departamento de Antropologia e PPGAS da UFPR. Desenvolveu o mestrado com uma pesquisa sobre os Yawanawá, no Acre, e doutorou-se pesquisando os Yaminawa, no Peru.

Diego Villar é Doutor em Antropologia pela Universidad de Buenos Aires e atualmente é pesquisador do CONICET. Pesquisa grupos indígenas no Chaco argentino (Chané) e os Chacobo, na Bolívia.

Miguel Carid Naveira é Doutor em Antropologia Social pelo PPGAS-UFSC e atualmente é professor adjunto no Departamento de Antropologia e PPGAS da UFPR. Desenvolveu seu trabalho de mestrado entre os Yawanawá, no Acre, 


\section{NOTAS}

1 Seeger, Anthony, da Matta, Roberto e Viveiros de Castro, Eduardo. 1987 [1979]. "A construção da pessoa nas sociedades indígenas brasileiras" In João Pacheco de Oliveira Filho (ed.). Sociedades indígenas e indigenismo no Brasil. Rio de Janeiro: Marco Zero.

2 Esta anedota foi explorada em um artigo vinte anos depois: Erikson, Philippe. 2008. "Obedient Things. Matis theory of materiality" In F. Santos Granero (ed.) The material life of things, University of Arizona Press.

3 Erikson, Philippe. 2003. "'Comme à toi jadis on l'a fait, fais-le moi à présent...'. Cycle de vie et ornementation corporelle chez les Matis (Amazonas, Brésil)" I'Homme 167-168: 129-152.

4 Erikson, Philippe. 1986. "Altérité, tatouage et anthropophagie chez les pano: la belliqueuse quête du soi". Journal de la Société des Américanistes LXXII: 185-209.

5 Erikson, Philippe. 1988. "Choix des Proies, choix des armes, et gestion du gibier chez les Matis et d'autres Amérindiens d'Amazonie" In Liliane Bodson (ed.) L'animal dans l'alimentation humaine, les critères de choix. Anthropozoologica, second n spécial: $211-220$.

Erikson, Philippe. 1988. "Apprivoisement et Habitat chez les Amérindiens Matis (Langue Pano, Amazonas, Brésil)", Anthropozoologica $9: 25-35$

6 Erikson, Philippe. 1987. "De l'apprivoisement à l'approvisionnement: chasse, alliance et familiarisation en Amazonie amérindienne". Techniques et cultures 9:105-140.

7 Erikson, Philippe. 2000. "Dialogues à vif... Note sur les salutations en Amazonie" In Aurore Monod Becquelin e Philippe Erikson (eds.) Les rituels du dialogue. Nanterre: Societé d'ethnologie. Versão traduzida em português: 2010. "Diálogos à flor da pele... Nota sobre as saudações na Amazônia". Campos. Revista de Antropologia Social (Curitiba) 11(2): 9-27.

8 Pouco tempo depois desta entrevista, entre fevereiro e agosto de 2010, Erikson passou seis meses entre os Chacobo, acompanhado de sua esposa, Hélène, e de sua filha caçula, Anna, então com 11 anos.

9 Os artigos em questão aqui são:

Erikson, Philippe. 2003. “Cana, Nabai, Baita y los demás... Comentarios sobre la onomástica Chacobo" Scripta Ethnologica 23: 59-74.

Erikson, Philippe. 1993. "A onomástica matis é amazônica?" In E. Viveiros de Castro \& M. Carneiro da Cunha (org.) Amazônia: etnologia e historia indígena. São Paulo: Núcleo de História Indígena e do Indigenismo USP/FAPESP. Pp. 323-338.

10 Erikson participou de várias filmagens entre os Matis, as principais sendo:

Matis. Return of the Ancestors. 1998. Essential TV for Discovery Channel, direção de Andy Jillings, 52 mn.

Matis. L'appel aux ancêtres. 2000. 95 West for Canal Plus. Direção de Gonzalo Arijon, 52 mn.

Jeux Amazoniens/The Amazon Games. 2005. ZED (Zoo Ethnological Documentary) for Arte, Canal Futura, Equator TV, Discovery Networks International, RTBF. Direção de Sandrine Leonardelli, $52 \mathrm{mn}$.

Tribe: the Matis. 2007. BBC Wales for BBC \& Discovery Channel. Direção de Wayne Derrick, 52 mn.

11 Erikson, Philippe. 2007. "Faces from the Past. Just how 'Ancestral' are Matis 'Ancestor Spirit' Masks?" In Carlos Fausto \& Michael Heckenberger (eds.) Time and Memory in Indigenous Amazonia. Anthropological Perspectives. Gainesville: University Press of Florida. Pp. 219-242.

12 "Habilitation à diriger des recherches" é a titulação que no sistema acadêmico francês credencia os professores para orientar teses de doutorado em áreas específicas de especialização.

13 Erikson, Philippe. 1987. "De l'apprivoisement a l'approvisionnement : chasse, alliance e familiarisation en Amazonie amérindienne". Techniques et cultures 9:105-140. 
14 Erikson, Philippe. 1986. "Altérité, tatouage et anthropophagie chez les pano: la belliqueuse quête du soi". Journal de la Société des Américanistes LXXII: 185-209.

15 Society for the Anthropology of Lowland South America.

16 Erikson, Philippe. 1988. “Chassez le Culturel..." In A. Cadoret (ed.) "Chasser le nature/...", Paris: Editions de L'EHESS. pp. 63-70. Trata-se de uma resenha do livro de Philippe Descola, La Nature Domestique.

17 Como explica Erikson no seu livro, as epidemias ocorridas na época do contato acabaram com a vida de dois terços da população matis. Erikson, Philippe. 1996 La griffe des aïeux. Marquage du corps et démarquages ethniques chez les Matis d'Amazonie. Louvain/ Paris: Peeters/SELAF.

18 Este temática tem sido abordada em detalhes em: Erikson, Philippe. 2002. "Reflexos de si, ecos de outrem. Efeitos do contato sobre a auto-representação Matis" In Bruce Albert e Alcida Rita Ramos (eds.) Pacificando o Branco. Cosmologias do Contato no Norte-Amazônico. São Paulo: Editora UNESP. pp. 179204. 